\title{
SPACING, PIT SIZE AND IRRIGATION INFLUENGE EARLY GROWTH PERFORMANGES OF FOREST TREE SPECIES
}

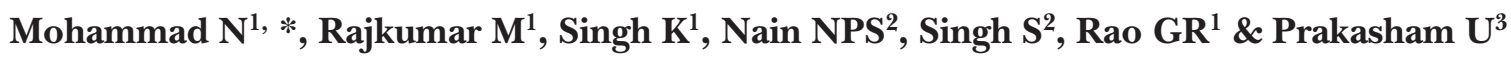 \\ ${ }^{1}$ Tropical Forest Research Institute, Jabalpur (Madhya Pradesh) - 482 021, India \\ ${ }^{2}$ Indian Council of Forestry Research and Education, Dehradun (Uttarakhand) - 248 006, India \\ ${ }^{3}$ Madhya Pradesh State Forest Department, Bhopal (Madhya Pradesh) - 4620 04, India \\ *naseer35518@gmail.com
}

Submitted May 2020; accepted August 2020

\begin{abstract}
This experiment is a standardisation of plantation techniques of four native, promising forestry species, namely, Dalbergia latifolia, Terminalia arjuna, Terminalia bellirica and Gmelina arborea, with respect to effects of tree spacing, pit size and irrigation. The experiment was set up in a tropical mixed deciduous forest patch of Madhya Pradesh, central India. We tested three spacings $(2 \mathrm{~m} \times 2 \mathrm{~m}, 3 \mathrm{~m} \times 3 \mathrm{~m}$ and $5 \mathrm{~m} \times 5 \mathrm{~m})$, three pit sizes $(30 \mathrm{~cm} \times 30 \mathrm{~cm} \times 30 \mathrm{~cm}, 45 \mathrm{~cm} \times 45 \mathrm{~cm} \times 45 \mathrm{~cm}$ and $60 \mathrm{~cm} \times 60 \mathrm{~cm} \times 60 \mathrm{~cm})$ and two moisture regimes (rainfed and irrigated). Growth data were recorded for four years, from the first year of plantation in 2013 to 2017. From the four-year growth performance, D. latifolia, T. arjuna and T. bellirica performed better in irrigated conditions, whereas G. arborea, performed well under rainfed condition. Terminalia bellirica performed best with largest pit size, i.e. $60 \mathrm{~cm} \times 60 \mathrm{~cm} \times 60 \mathrm{~cm}$, while the other three species performed best with $45 \mathrm{~cm} \times 45 \mathrm{~cm} \times 45 \mathrm{~cm}$ pit size. In terms of tree spacing, G. arborea and D. latifolia responded best to $3 \mathrm{~m} \times 3 \mathrm{~m}$ spacing while T. arjuna and T. bellirica performed best with $5 \mathrm{~m} \times 5 \mathrm{~m}$ spacing.
\end{abstract}

Keywords: Rainfed, irrigated, collar diameter, seedling height, central India

\section{INTRODUCTION}

Plantation forests represent about $4 \%$ of the global forest area and have potential to meet the world's entire wood requirements (Fenning \& Gershenzon 2002) and, therefore, are now taken up as systematic programmes by many countries and are expected to increase with time (Putz 2015). Presently, India is the second most populous country in the world and fails to meet the population's large demand for wood from its own resources and is a net importer of timber and allied products. India's timber imports in 2025 and 2030 are projected to be 27.01 and 31.5 million $\mathrm{m}^{3}$ respectively. In India, Forest Development Corporations (FDCs) are entrusted with the mandate to raise plantations of economically important species to fulfil the timber demand of the country. Although, the FDCs have not been able to fulfil this demand, they contribute significantly $(\sim 60 \%)$ to the total annual production of timber from forest (Agarwal \& Saxena 2017). Until recently, FDCs, wood-based industries and plantation companies were more inclined towards the introduction and cultivation of exotic trees such as Eucalyptus, Casuarina, Poplar and Leucaena to fulfil the requirement for raw wood. However, cultivation of exotic species is not a permanent solution as they vigorously invade over indigenous species. Besides, exotic tree species have many limitations such as site specificity and higher moisture and nutrient requirements. Additionally, arguments surrounding the negative effects of monoculture of exotic trees on soil health, ground water and ecological threats to native vegetation lead to more ambiguity.

In this context, indigenous species such as Dalbergia latifolia, Terminalia arjuna, Ailanthus excelsa, Pterocarpus marsupium, Terminalia bellirica, Melia dubia, Gmelina arborea, Azadirachta indica, Shorea robusta, Anogeissus latifolia, Lagerstroemia parviflora, Toona ciliata, Mangifera spp., Quercus spp., Dalbergia spp., and Bombax spp. are promising species and have great potential to fulfil both timber and biomass demands of the country, with added advantage of being native. However, there exist many hurdles in promoting these species for commercial cultivations, including absence of improved planting stock, lack of standardised plantation techniques, package of practices and cost-benefit economics. Due to the government's 
recent emphasis on the importance of native species, considerable progress has been made to prioritise native species over exotics.

There are many reports indicating significant effect of irrigation, spacings and pit sizes on the overall growth rate of forest tree plantations. Such reports are ample for temperate trees (Linder et al. 1987, Neilsen et al. 1997, Albaugh et al. 2004), but limited for indigenous multipurpose tropical forest trees species such as D. latifolia, T. arjuna, T. bellirica and G. arborea (Priya \& Bhat 1999, Zahabu et al. 2015).

The present study was aimed at raising an experimental plantation with different planting designs so as to investigate the effect of inter-tree spacings, pit sizes and irrigation on early growth parameters of D. latifolia, T arjuna, T. bellirica and G. arborea for better understanding and optimising standard plantation techniques. We hypothesised that appropriate spacing, pit size and moisture availability in early growth years would determine the success of native forest tree plantations.

\section{MATERIALS AND METHODS}

\section{Site selection and procurement of planting stock}

Suitable site for the establishment of plantation was finalised after consultation with the State Forest Department of Madhya Pradesh. The site chosen was a tropical mixed deciduous forest patch located in Moyanala village of Bijadandi range, Mandla (West) Forest Division (Figure 1). The plot was cleared of weeds and debris in AprilMay 2013. Quality planting stocks of the targeted species, i.e. D. latifolia, T. arjuna, T. bellirica, and G. arborea were procured from the nursery of the Forest Research and Extension Circle (Jabalpur), Madhya Pradesh Forest Department.

\section{Experimental design}

Factorial experiment was designed with three factors, namely, $A$ (condition): $A_{1}=$ irrigated and $\mathrm{A}_{2}=$ rainfed; $\mathrm{B}$ (spacing): $\mathrm{B}_{1}=2 \mathrm{~m} \times 2 \mathrm{~m}, \mathrm{~B}_{2}=$

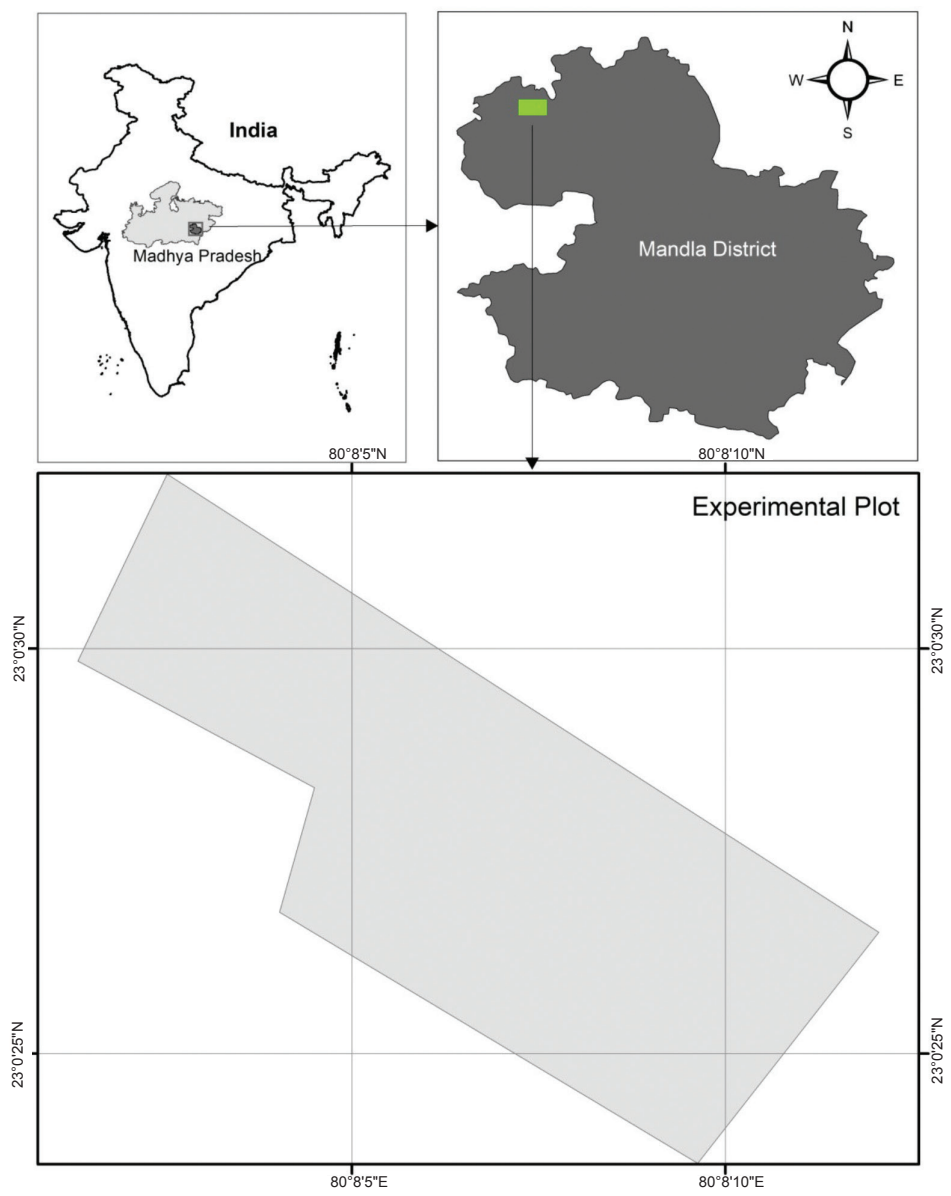

Figure 1 Location of the experimental site in Mandla (West) Forest Division, Madhya Pradesh, India 
$3 \mathrm{~m} \times 3 \mathrm{~m}$ and $\mathrm{B}_{3}=5 \mathrm{~m} \times 5 \mathrm{~m}$; and $\mathrm{C}$ (pit size): $\mathrm{C}_{1}=30 \mathrm{~cm} \times 30 \mathrm{~cm} \times 30 \mathrm{~cm}, \mathrm{C}_{2}=45 \mathrm{~cm} \times 45 \mathrm{~cm}$ $\times 45 \mathrm{~cm}$ and $\mathrm{C}_{3}=60 \mathrm{~cm} \times 60 \mathrm{~cm} \times 60 \mathrm{~cm}$. Thus, factor A had two levels and factors B and C had three levels each. For each forestry species, 18 treatment combinations were tested (Table 1). The experiment was laid out in randomised complete block design with two replications. One-year-old seedlings were planted in June 2013. Irrigation was provided once a week in summer using buried clay pot method (Bainbridge 2001), which is one of the most efficient traditional systems of irrigation. All standard package of practices were followed to raise a healthy plantation.

\section{Data recording and statistical analysis}

Height and collar diameter were measured on 12 seedlings per plot in December every year till 2017 , i.e. up to four years. Three factor analyses of variance (Tucker 1966) was performed to assess the effects of conditions (rainfed/irrigation), spacings and pit sizes of growth parameters using statistical package OPSTAT, version 1998.

\section{RESULTS AND DISCUSSION}

Average performances of $D$. latifolia, T. arjuna, $T$. bellirica and $G$. arborea for the four years (2013-2017) are presented in Figure 2. Statistical significances of the effects of irrigation/rainfed, spacings, pit sizes and their interactions on growth parameters of the four species studied for 2013-2017 are presented in Table 2. Seedling height and collar diameter of $D$. latifolia were not affected by the three factors, i.e. condition, spacing, pit size and their interactions during the four years period. Highest average seedling height $(148.62 \mathrm{~cm})$ was recorded under irrigated condition with $3 \mathrm{~m} \times 3 \mathrm{~m}$ spacing and $45 \mathrm{~cm} \times$ $45 \mathrm{~cm} \times 45 \mathrm{~cm}$ pit size (i.e. $\mathrm{A}_{1} \times \mathrm{B}_{2} \times \mathrm{C}_{2}$ ). Lowest height $(100.62 \mathrm{~cm})$ was observed under rainfed condition with $5 \mathrm{~m} \times 5 \mathrm{~m}$ spacing and $60 \mathrm{~cm} \times$ $60 \mathrm{~cm} \times 60 \mathrm{~cm}$ pit size. Under rainfed condition, highest average height was recorded with $5 \mathrm{~m} \times$ $5 \mathrm{~m}$ spacing and $30 \mathrm{~cm} \times 30 \mathrm{~cm} \times 30 \mathrm{~cm}$ pit size (Figure 2). Earlier published reports indicate that full light, porous soil, free of weeds infestation and adequate moisture in the soil are the decisive factors for overall development of the D. latifolia seedlings (Kadambi 1954). Dalbergia latifolia survives up to temperatures of $37-50^{\circ} \mathrm{C}$ and is well known as a drought tolerant tree, but at seedling stage, it is sensitive to drought (Troup 1921). However, in the present investigation, irrigation did not influence the growth significantly, but its effect on D. latifolia seedling height was evident and maximum average height was recorded with irrigated condition. Therefore, irrigation was recommended for the first three years of planting. Linear increase in dry weight was observed for Dalbergia sissoo, Eucalyptus camaldulensis and E. grandis after irrigation (Hunter 2001). Similarly, D. sissoo seedlings also showed better growth and biomass production in an experiment to assess the effect of soil water stress regimes on biomass production (Singh \& Singh 2009).

Although T. arjuna and T. bellirica have varied uses such as timber, biomass and medicine, research on standardisation of plantation techniques and package of practices for raising healthy plantations of this species are lacking. Conditions (irrigated/rainfed), and their interaction with spacings and pit sizes had significantly affected T. arjuna seedling

Table 1 Three factorial experiments designed to assess the effects of spacing, pit sizes and irrigation on four different indigenous forestry species

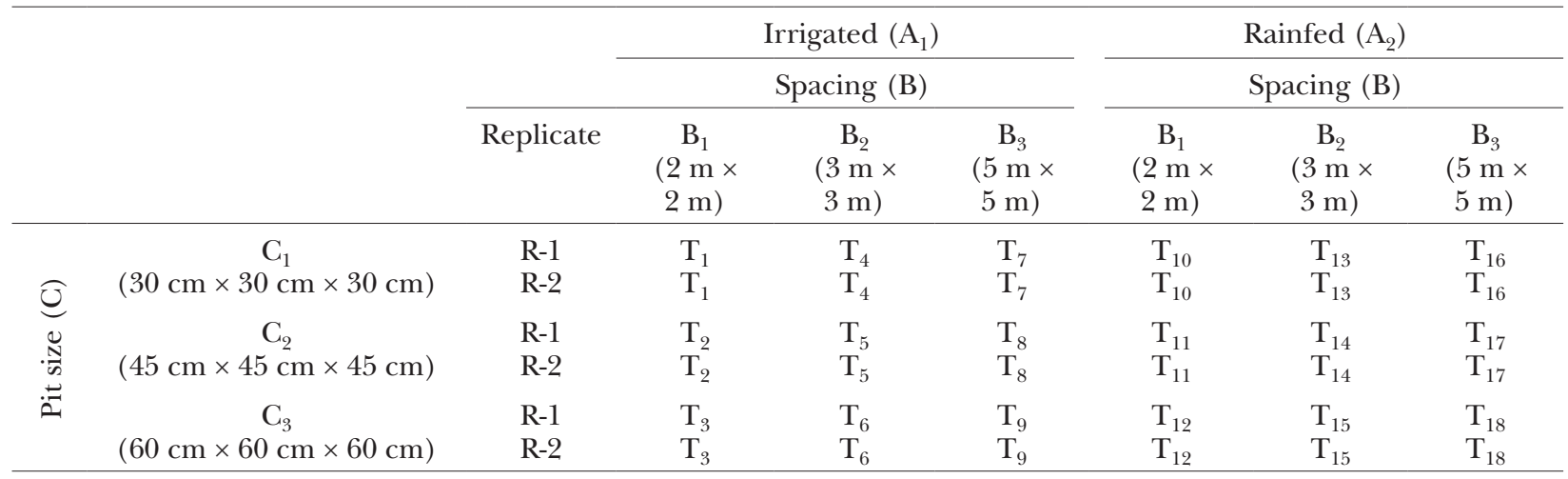



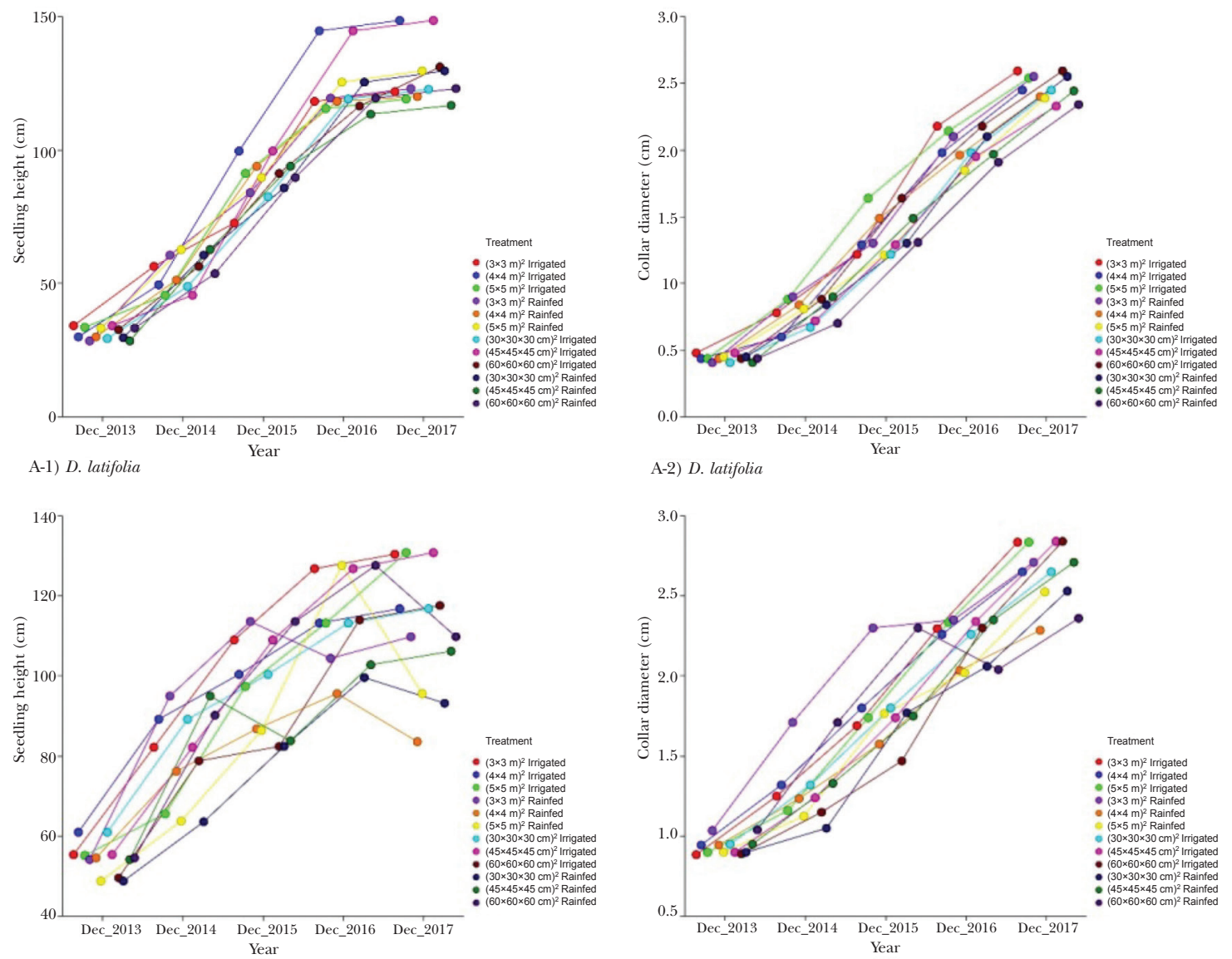

B-1) T. arjuna
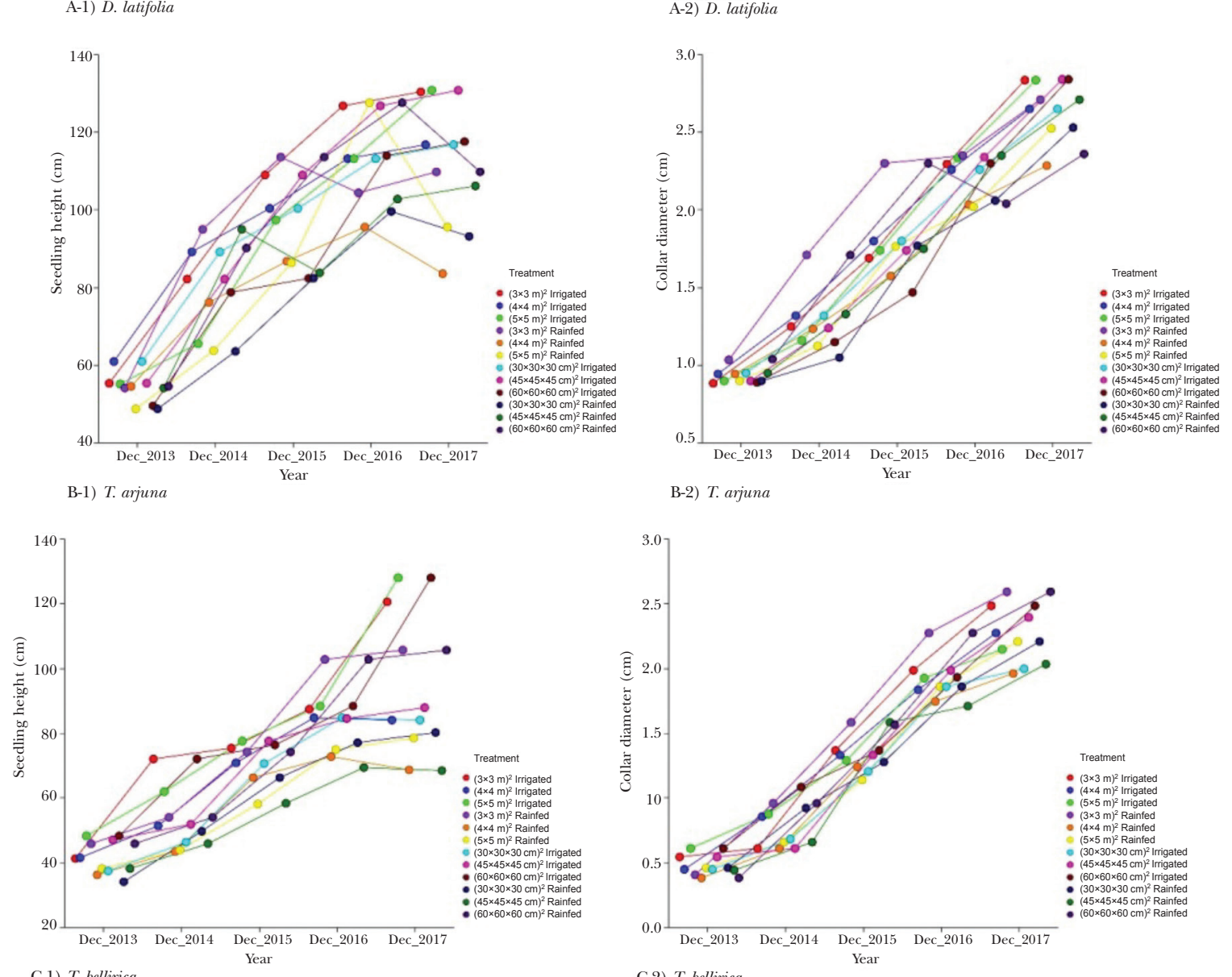

C-1) T. bellirica

C-2) T. bellirica
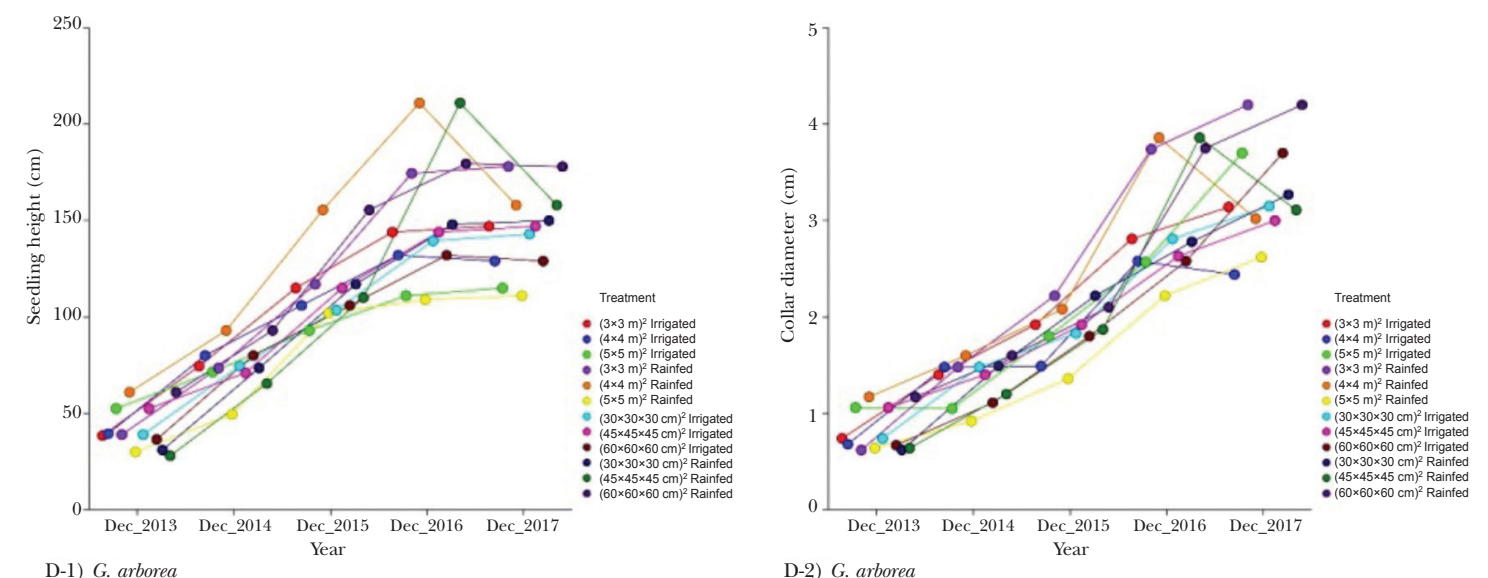

Figure 2 Yearly growth performance of Dalbergia latifolia (A-1 \& 2), Terminalia arjuna (B-1 \& 2), T. bellirica (C-1 \& 2) and Gmelina arborea (D-1 \& 2) under different planting spacings, pit sizes and moisture regimes 

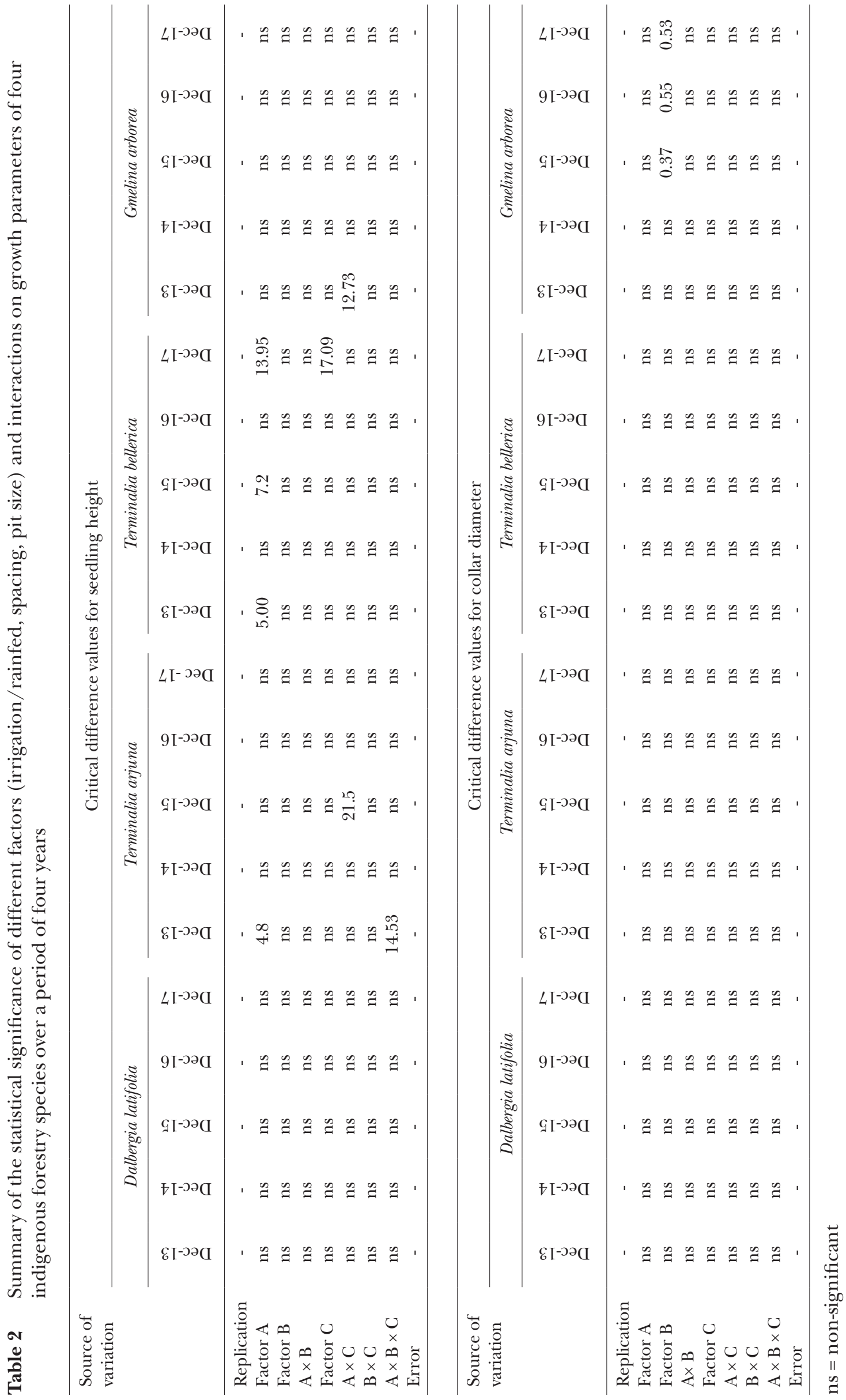
height in one or more years during the study period. However, the effect of irrigation and its interaction with pit spacings and pit sizes became insignificant as growth progressed. At the end of fifth year, only factor spacing exhibited significant influence on the seedling height. Highest average seedling height $(130.87 \mathrm{~cm})$ was recorded in irrigated condition with $5 \mathrm{~m} \times$ $5 \mathrm{~m}$ spacing with $45 \mathrm{~cm} \times 45 \mathrm{~cm} \times 45 \mathrm{~cm}$ pit size $\left(\mathrm{A}_{1} \times \mathrm{B}_{3} \times \mathrm{C}_{2}\right)$ followed by $130.50 \mathrm{~cm}$ in irrigated condition with $2 \mathrm{~m} \times 2 \mathrm{~m}$ spacing and $45 \mathrm{~cm} \times$ $45 \mathrm{~cm} \times 45 \mathrm{~cm}$ pit size $\left(\mathrm{A}_{1} \times \mathrm{B}_{1} \times \mathrm{C}_{2}\right)$. A similar trend was recorded for collar diameter. Highest value $(2.83 \mathrm{~cm})$ was recorded in $\mathrm{A}_{1} \times \mathrm{B}_{3} \times \mathrm{C}_{2}$ and in $\mathrm{A}_{1} \times \mathrm{B}_{1} \times \mathrm{C}_{3}$ followed by $2.53 \mathrm{~cm}$ in $\mathrm{A}_{1} \times \mathrm{B}_{1} \times$ $\mathrm{C}_{2}$. However, these values were not significantly different (Figure 2).

Seedling height of $T$. bellirica was also significantly affected by condition (irrigated/ rainfed) and pit size, but effects of spacing and interactions were statistically insignificant. Highest average height $(128 \mathrm{~cm})$ was obtained under irrigated condition with $\mathrm{A}_{1} \times \mathrm{B}_{3} \times \mathrm{C}_{3}$ followed by $120.5 \mathrm{~cm}$ in $\mathrm{A}_{1} \times \mathrm{B}_{1} \times \mathrm{C}_{3}$ treatment combination. Under rainfed condition, highest average seedling height $(105.62 \mathrm{~cm})$ was observed in $\mathrm{A}_{2} \times \mathrm{B}_{1} \times \mathrm{C}_{3}$ treatment. None of the factors and their interactions exhibited significant effect on collar diameter.

Our findings concur with the recommendation by NMPB (2008) that $6 \mathrm{~m} \times 6 \mathrm{~m}$ spacing and $45 \mathrm{~cm}$ $\times 45 \mathrm{~cm} \times 45 \mathrm{~cm}$ pit size should be applied for Terminalia spp. Olaoye and Oyun (2019) investigated early growth of indigenous tree species in response to watering regimes and found that Terminalia spp. require watering thrice a week for optimal growth. Terminalia spp. prefer moist physical environment and are largely distributed along the bank of streams (Paarakh 2010) and riparian forests (Nagaraja et al. 2014). The present investigation also showed better results of growth parameters with irrigated condition and a wider planting spacing of $5 \mathrm{~m} \times$ $5 \mathrm{~m}$ was best for T. arjuna and T. bellirica .

Height and collar diameter of G. arborea were significantly affected by spacing but not irrigation and pit size. However, in the second year of planting, interaction between irrigation and spacing had significant effects on height and collar diameter, but these effects became non-significant in later years. At the end of fifth year, highest average height $(260.87 \mathrm{~cm})$ was recorded under rainfed condition with $3 \mathrm{~m} \times 3 \mathrm{~m}$ spacing and $45 \mathrm{~cm} \times 45 \mathrm{~cm} \times 45 \mathrm{~cm}$ pit size followed by $192 \mathrm{~cm}$ in $2 \mathrm{~m} \times 2 \mathrm{~m}$ spacing and $60 \mathrm{~cm} \times 60 \mathrm{~cm} \times 60 \mathrm{~cm}$ pit size. Under irrigated condition, highest average height $(146.75 \mathrm{~cm})$ was recorded in $2 \mathrm{~m} \times 2 \mathrm{~m}$ spacing and $45 \mathrm{~cm} \times$ $45 \mathrm{~cm} \times 45 \mathrm{~cm}$ pit size. For G. arborea, Mayavel et al. (2014) recommended $3 \mathrm{~m} \times 3 \mathrm{~m}$ spacing and $45 \mathrm{~cm} \times 45 \mathrm{~cm} \times 45 \mathrm{~cm}$ pit for optimal growth. It is a light-demanding and drought-resistant species and can adapt well to a wide range of soil and climatic conditions of tropical and subtropical regions (Chaturvedi et al. 2017). This could be one of the reasons for the insignificant difference in growth performance of $G$. arborea between rainfed and irrigated conditions in the present study.

Seedling collar diameters of the four species were not significantly affected by the studied factors and their interactions. Seedling height was generally more affected by irrigation and spacing compared with collar diameter. Effect of the spacing will be more visible in later years after full canopy development due to competition (Smith \& Reukema 1986, Hebert et al. 2016). Determination of proper spacing is important for producing more quality wood (Kerr 2003, Rais et al. 2014).

It is difficult to raise successful plantations in the tropics, because tropical trees are highly sensitive to site conditions, and several plantations in the tropics have poor rates of success. Therefore, with a high degree of confidence, assessments from the current study can be applied elsewhere in the tropics with parallel land contexts. Findings of the study are not only valuable for foresters and plantation managers, but also for cross-sectoral approaches such as agroforestry. Species such as G. arborea and D. latifolia have high prospects for rural livelihood improvement through agroforestry (Parthiban et al. 2014), especially when countries are prioritising towards climate solutions (Deb et al. 2018) for achieving their Nationally Determined Contributions in mitigating climate change through afforestation, reforestation, sustainable forest management and improved forest plantations.

\section{CONCLUSIONS}

Restoration of degraded land is gaining importance as never before and is becoming top priorities of respective governments. 
Therefore, it is necessary to intensify relevant and practical field research into plantation techniques of forestry species. It is in this context that the findings of our study, especially the species-wise recommendations, are vital. We concluded that D. latifolia, T. arjuna and T. bellirica performed better in irrigated conditions, whereas $G$. arborea performed well under rainfed condition. This suggested that G. arborea was suitable for agroforestry system. Terminalia bellirica performed best with largest pit size, i.e. $60 \mathrm{~cm} \times 60 \mathrm{~cm} \times 60 \mathrm{~cm}$, while the other three species performed best with $45 \mathrm{~cm} \times 45 \mathrm{~cm} \times 45 \mathrm{~cm}$ pit size. In terms of tree spacing, G. arborea and D. latifolia responded best to $3 \mathrm{~m} \times 3 \mathrm{~m}$ spacing while T. arjuna and T. bellirica performed best to $5 \mathrm{~m} \times 5 \mathrm{~m}$ spacing. Irrigation, pit size and spacing with periodic silvicultural thinning are highly recommended for mid-term economic returns.

\section{ACKNOWLEDGEMENTS}

The authors are grateful to The Director, Tropical Forest Research Institute, Jabalpur (Madhya Pradesh) for extending the required field and laboratory support. Authors are also thankful to Subramanyam P and Chandra G for helping in designing the experiment; Kunjam KK, Jhariya S and Joshi M for helping in data collection; and Gupta D for preparing the site map. Financial grant extended by the Madhya Pradesh State Forest Department, Bhopal is duly acknowledged.

\section{REFERENCES}

Agarwal S \& Saxena AK. 2017. The Puzzle of Forest Productivity: Are Forest Development Corporations Solving it RIGHT? Centre for Science and Environment, New Delhi.

Albaugh TJ, Allen HL, Dougherty PM \& Johnsen KH. 2004. Long term growth responses of loblolly pine to optimal nutrient and water resource availability. Forest Ecology and Management 192: 3-19. https:/ / doi. org/10.1016/j.foreco.2004.01.002

Bainbridge DA. 2001. Buried clay pot irrigation: a little known but very efficient traditional method of irrigation. Agricultural Water Management 48: 79-88. https://doi.org/10.1016/ S0378-3774(00)00119-0

Chaturvedi OP, Handa AK, Uthappa AR et al. 2017. Promising Agroforestry Tree Species in India. Central Agroforestry Research Institute, Jhansi.

Deb JC, Phinn S, Butt N \& McAlpine CA. 2018. Climate change impacts on tropical forests: identifying risks for tropical Asia. Journal of Tropical Forest Science 30: 182-194.
Fenning TM \& Gershenzon J. 2002. Where will the wood come from? Plantation forests and the role of biotechnology. Trends in Biotechnology 20: 291-296. https://doi.org/10.1016/ S0167-7799(02)01983-2

Hebert F, Krause C, Plourde PY, Achim A, Pregent G \& MENETRIER J. 2016. Effect of tree spacing on tree level volume growth, morphology, and wood properties in a 25-year-old Pinus banksiana plantation in the boreal forest of Quebec. Forests 7: 276-291. https:// doi.org/10.3390/f7110276

Hunter I. 2001. Effect on above ground biomass and nutrient uptake of three tree species (Eucalyptus camaldulensis, Eucalyptus grandis and Dalbergia sissoo) as affected by irrigation and fertiliser, at 3 years of age, in southern India. Forest Ecology and Management 144: 189-200. https://doi.org/10.1016/S03781127(00)00373-X

Kadambi K. 1954. The Silviculture of Dalbergia latifolia. Monograph of Indian Trees No. 1. Government of India, Delhi.

KERR G. 2003. Effects of spacing on the early growth of planted Fraxinus excelcior L. Canadian Journal of Forest Research 33: 1196-1207. https://doi.org/10.1139/ $\mathrm{x} 03-041$

Linder S, Benson ML, Myers BJ \& Raison RJ. 1987. Canopy dynamics and growth of Pinus radiata. I. Effects of irrigation and fertilization during a drought. Canadian Journal of Forest Research 17: 1157-1165. https://doi.org/10.1139/x87-179

Mayavel A, Soosai Raj J, Singh BG \& Krishnakumar N. 2014. Cultivation techniques for Gmelina arborea. Pp 23-27 in Buvaneswaran C et al. (eds) Transfer of Tree Cultivation Technologies to Krishi Vigyan Kendras (KVKs) of Tamil Nadu and Puducherry. Institute of Forest Genetics and Tree Breeding, Coimbatore.

Nagaraja BC, Sunil C \& Somashekar RK. 2014. Protection of riparian habitats to conserve keystone species with reference to Terminalia arjuna: a case study from south India. Pp 95-109 in Grillo O (ed) Biodiversity-The Dynamic Balance of the Planet. IntechOpen, London.

NMPB (National Medicinal Plants Board). 2008. AgroTechniques of Selected Medicinal Plants. Volume I. TERI Press, New Delhi.

Neilsen GH, Parchomchuk P, Berard R \& Neilsen D. 1997. Irrigation frequency and quantity affect root and top growth of fertigated 'McIntosh' apple on M.9, M.26 and M.7 rootstock. Canadian Journal of Plant Science 77: 133-139. https://doi.org/10.4141/P96-095

Olaoye BA \& Oyun MB 2019. Early growth of selected indigenous tree species in response to watering regime. Tropical Plant Research 6: 192-198.

PAARakh PM. 2010. Terminalia arjuna (Roxb.) Wt. and Arn.: a review. International Journal of Pharmacology 6: 515-534. https://doi.org/10.3923/ijp.2010.515.534

Parthiban KT, Umarani R, Kanna SU, Sekar I, Rajendran P \& Durairasu P. 2014. Industrial Agroforestry Perspectives and Prospectives. Scientific Publishers, New Delhi.

PrIYA PB \& BHAT KM. 1999. Influence of rainfall, irrigation and age on the growth periodicity and wood structure in teak (Tectona grandis). IAWA Journal 20: 181-192. https://doi.org/10.1163/22941932-90000678

Putz FE. 2015. Intensification of tropical silviculture. Journal of Tropical Forest Science 273: 285-288. 
Rais A, Poschenrieder W, Pretzsch H \& Kuilen JWG. 2014. Influence of initial plant density on sawn timber properties for Douglas-fir (Pseudotsuga menziesii (Mirb.) Franco). Annals of Forest Science 71: 617-626. https://doi.org/10.1007/s13595-014-0362-8

SingH G \& SingH B. 2009. Effect of varying soil water stress regimes on nutrient uptake and biomass production in Dalbergia sissoo seedlings in Indian desert. Journal of Forestry Research 20: 307-313. https://doi.org/10.1007/s11676-009-0053-8

Smith HJG \& Reukema DL. 1986. Effects of plantation and juvenile spacing on tree and stand development. Pp 239-245 in Oliver CD et al. (eds) Proceedings of a Symposium on Douglas-Fir: Stand Management for the Future. 18-20 June 1985, Seattle.

Troup RS. 1921. The Silviculture of Indian Trees. Clarendon Press, Oxford.

Tucker LR. 1966. Some mathematical notes on three-mode factor analysis. Psychometrika 31: 279-311. https:/ / doi. org/10.1007/BF02289464

Zahabu E, Raphael T, Chamshama SAO, Iddi S \& Malimbwi RE. 2015. Effect of spacing regimes on growth, yield, and wood properties of Tectona grandis at Longuza Forest Plantation, Tanzania. International Journal of Forestry Research. Article ID 469760. https://doi. org $/ 10.1155 / 2015 / 469760$ 